\title{
THE ES/CICAD/OAS SCHOOLS OF NURSING PROJECT: A MODEL OF EXCELLENCE FOR PROFESSIONAL AND SCIENTIFIC DEVELOPMENT ON DRUG RELATED ISSUES IN LATIN AMERICA
}

\author{
Maria da Gloria Miotto Wright ${ }^{1}$, Maria Juliana Lujan ${ }^{2}$
}

\begin{abstract}
${ }^{1}$ Ph.D. Public Health Nurse. Drug Specialist. Coordinator Educational Development Program (EDP) - Demand Reducion Section (DRS) of the Interamerican Drug Abuse Control Commission (CICAD) of the Secretariat for Multidimensional Security (SMS) of the Organization of American States (OAS). Washington, DC, United Sates. E-mail: gwright@oas.org

2 BS. Political Science, Drug Specialist, Project Assistant of EDP/DRS/CICAD/SMS/OAS, Washigton, DC, United States. E-mail: mlujan@oas.org
\end{abstract}

\begin{abstract}
This paper presents the Executive Secretariat of Interamerican Drug Abuse Control Commission (ES/CICAD)'s successful experience introducing drug related content into nursing curricula, fostering the implementation of outreach activities at the community level, and promoting research studies on drug issues in Latin America. The "Critical-holistic international health model applied to the drug phenomenon" is used as the project's theoretical framework. The three basic components of the project are education, outreach activities, and drug research studies, which provide the scientific basis for the development and advancement of future nursing professionals to work and study drug issues in Latin America. Through this project, more than 50,000 nursing students have been or are being educated on drug-related issues; the participating schools have implemented 400 outreach activities, developed more than 500 research studies on drug-related issues, and published more than 270 articles in national and international peer-reviewed journals. The ES/CICAD Schools of Nursing Project has served as a model to address the drug phenomenon from an international health perspective for other academic areas such as medicine, public health, education, psychology, social work, social communication, and law in Latin America.
\end{abstract}

DESCRIPTORS: Universities. Schools. Nursing. Drugs. Latin America.

\section{O PROJETO DA SE/CICAD/OEA COM AS ESCOLAS DE ENFERMAGEM: UM MODELO DE EXCELÊNCIA PARA O DESENVOLVIMENTO PROFISSIONAL E CIENTÍFICO COM TEMAS RELACIONADOS SOBRE DROGAS NA AMÉRICA LATINA}

\begin{abstract}
RESUMO: Este trabalho apresenta uma experiência de sucesso da Secretaria Executiva da Comissão Interamericana para o Controle do Abuso de Drogas (SE/CICAD) relacionado com a introdução do conteúdo de drogas nos currículos de enfermagem, além da implementação das atividades de extensão ao nível da comunidade, e promover o desenvolvimento de pesquisas na temática de drogas. O modelo "Crítico-holísitico de saúde internacional aplicado ao fenômeno das drogas" foi utilizado como referencial teórico para o projeto. Os três compentes básicos do projeto são educação, atividades de extensão, e pesquisa sobre drogas, o que oferece as bases científicas para o desenvolvimento e avance do futuro professional de enfermagem para trabalhar e estudar os problemas relacionados com drogas na América Latina. Através deste projeto, mais de 50.000 estudantes de enfermagem foram educados em temas relacionados com drogas, as escolas participantes do projeto tem implementado mais de 400 atividades de extensão, mais de 500 pesquisas foram realizadas relacionadas com os diferentes aspectos das drogas, e mais de 270 artigos científicos foram publicados em revistas nacionais e internacionais. O projeto das escolas de enfermagem da SE/CICAD tem servido de modelo para analisar o fenômeno das drogas desde a perspectiva de saúde internacional em outras áreas acadêmicas como medicina, saúde pública, educação, psicología, serviço social, comunicação social e direito na América Latina.
\end{abstract}

DESCRIPTORES: Universidades. Escolas. Enfermagem. Drogas. América Latina.

\section{EL PROYECTO DE LA SE/CICAD/OEA CON LAS ESCUELAS DE ENFERMERÍA: UN MODELO DE EXCELENCIA PARA EL DESARROLLO PROFESSIONAL Y CIENTÍFICO EN TEMAS RELACIONADOS CON DROGAS EN AMÉRICA LATINA}

RESUMEN: Este trabajo presenta la experiencia exitosa de la Secretaria Ejecutiva da Comisión Interamericana para el Control del Abuso de Drogas (SE/CICAD) de introducir el contenido de drogas en los currícula de enfermería, además de la implementación de actividades de extensión a nivel de la comunidad, y promover estudios de investigación en la temática de drogas. El modelo "Crítico-holístico de salud internacional aplicado al fenómeno de las drogas" fue utilizado como referencial teórico para el proyecto. Los tres componentes básicos del proyecto son educación, actividades de extensión, y estudios de investigación en drogas, lo cual ofrece las bases científicas para el desarrollo y avance del futuro profesional de enfermería para trabajar y estudiar problemas relacionados con drogas en América Latina. A través de este proyecto, más de 50,000 estudiantes de enfermería fueron educados en temas relacionados con drogas; las escuelas participantes del proyecto han implementado más de 400 actividades de extensión, más de 500 estudios relacionados con los diferentes aspectos de las drogas y han publicado más de 270 artículos científicos en revistas nacionales o internacionales. El proyecto de las escuelas de enfermería de la SE/CICAD ha servido como modelo para mirar el fenómeno de las drogas desde la perspectiva de salud internacional en otras áreas academica como la medicina, salud pública, educación, psicología, servicio social, comunicación social y derecho en América Latina.

DESCRIPTORES: Universidades. Escuelas. Enfermería. Drogas. América Latina. 


\section{INTRODUCTION}

Among the lingering challenges and unresolved problems of the $21^{\text {st }}$ century are a complex maelstrom of issues revolving around controlled substances. For years, countries have faced many difficulties when dealing with the control of production, transport and consumption of illicit and licit drugs. Drug use and abuse have become important issues on the international and national agendas as a consequence of the damage they cause to the social, economic and political fabric in really all the countries of the hemisphere.

Illicit drugs problems have been studied in many research projects while international, governmental and non-governmental organizations, and professional associations have conferred on the issue. ${ }^{1}$ Inter-American Drug Abuse Control Commission (CICAD) Multilateral Evaluation Mechanism (MEM) ${ }^{2}$ has implemented five rounds of analysis in which member countries of the Organization of American States (OAS) have been evaluated by their peers on their implementation of national drug policies and strategies. In the last round of evaluation more than 300 recommendations for policy changes in the areas of institutional building, demand reduction, supply reduction and control measures were issued to 34 members states.

As we continue to evolve into a global community, one nation's public health issues, such as drug abuse, become the concern of all nations. The scope and consolidation of a new economic paradigm encompasses the process of globalization, which involves an increased integration of diverse economies and societies as a result of greater flows of goods, capital, people, and ideas. This integration has economic benefits, as well as consequences for health and drug issues. ${ }^{3-4}$

Many of the current and future drug related health problems will continue to be global or multinational in nature. Some of the challenges in dealing with these problems require innovative initiatives, partnerships and approaches to the education of health-related professionals.

This paper presents the Executive Secretariat of Interamerican Drug Abuse Control Commission (ES/CICAD)'s successful experience of partnership with universities in Latin America to introduce drug-related content into undergraduate and graduate university nursing curricula, fostering the implementation of extension activities at the community level, and promoting the development of research studies on drug issues, as a model for other academic areas such as medicine, public health, education, psychology, social work, and law in Latin America.

\section{JUSTIFICATION}

Recent social and technological developments have directly or indirectly abetted the production, trade and consumption of illicit and licit drugs in the Americas and in the world. To overcome this situation, in 1986, the member states of the OAS created the CICAD, ten years later, CICAD adopted the Anti-Drug Strategy in the hemisphere as an expression of the need for shared responsibility to deal with drug issues in the Americas. This integrated approach has facilitated the design of international and national policies of shared interest to reduce the supply and consumption of drugs in the Americas. ${ }^{5} \mathrm{On}$ May 2010, in Washington, DC, the CICAD/OAS approved a new version of the Anti-Drug Strategy entitled "Hemispheric Drug Strategy", and on June $5^{\text {th }}, 2010$, it was adopted by the General Assembly of the OAS in its $40^{\text {th }}$ regular session, Lima, Peru. In May 2011, the CICAD/OAS, in Paramaribo/Suriname approved the "Plan of Action 2011-2015" for the new Hemispheric Drug Strategy. ${ }^{6}$

Around the world, national governments are emphasizing increasingly the importance of the development of activities related to drug abuse reduction, paying specific attention to the preparation of human resources for the promotion of healthy and sustainable lifestyles, prevention, treatment, rehabilitation, and social integration. Health professionals are key actors to work and perform research in this area.

Taking into consideration this situation, in 1997, ES/CICAD/OAS presented to the Government of Japan a proposal to initiate a pilot to work with Latin American schools of nursing. The project aimed to introduce drug-related course content into undergraduate and graduate nursing curricula, develop extension activities at the community level and carry out research studies on drug-related problems, so the schools could prepare future nursing professionals with scientific knowledge and technical skills to work and study drug issues. 
The nursing profession constitutes the single largest segment of the health care work force. Nurses maintain close contact with individuals, families, and communities; therefore, they are best able to identify the variety of problems related to illicit drugs.?

Investing in the development of future nursing professionals in the areas of promotion of healthy and sustainable lifestyles, prevention of drug use and abuse, treatment, rehabilitation, and social integration, requires designing international and national policies to support such initiatives, as well as the development of new models of partnership to carry out the necessary activities. Hereby, we present an overview of ES/CICAD/ OAS Schools of Nursing Project in Latin America as a model of professional excellence in the area of drug demand reduction.

\section{ES/CICAD/OAS UNIVERSITY PARTNER- SHIP PROJECT IN LATIN AMERICA}

The ES/CICAD/OAS University Partnership Project uses the Critical-Holistic International Health Framework Applied to the Drug Phenome- non. ${ }^{8-9}$ This framework uses a dialectical approach for the analysis of drug issues in the Americas, including macro and micro dimensions. The methodology provides the foundation to bring together international and national participants to provide scientific and technological support for the development of educational curricula with drug content (and faculty development), extension activities at the community level, and implementation of research studies on drug issues.

Figure 1 summarizes the structure of the model. In the macro-political context, the model addresses the dimension of power, interest, knowledge, and leadership regarding drug issues in international relations. In the micro-political context, the model is concerned with: (i) the international dimension of drug issues at the domestic level; and (ii) the strategic development of the country regarding drug control and the impact of drug abuse on the health of individuals, families, and communities. The Critical-holistic international health model applied to the drug phenomeon has supported the design of the entire project, as well as its operationalization at ES/CICAD/OAS and at the universities. ${ }^{10}$

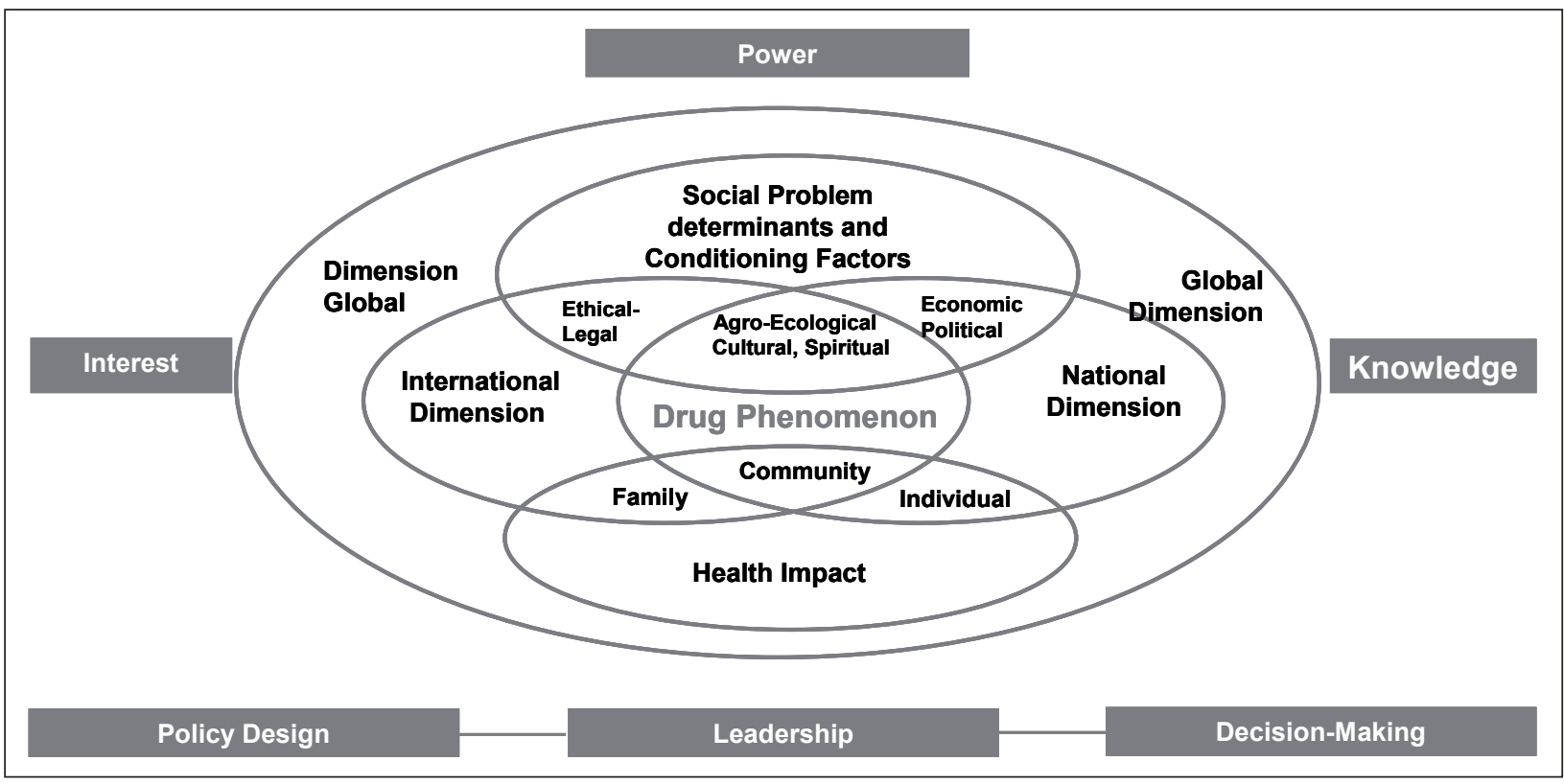

Figure 1 - Critical holistic international-health model applied to study drug phenomenon in the Americas (Wright, 1999)

At ES/CICAD/OAS, the project is managed at the Demand Reduction Section through the Educational Development Program (EDP). At the university level the project is implemented with the Schools of Nursing as showing in picture 1. 
Picture 1 - Structure of project at university level

\begin{tabular}{|l|l|}
\hline \multicolumn{1}{|c|}{ Items } & \multicolumn{1}{c|}{ Composition } \\
\hline Project Coordinator & Dean of the School of Nursing. \\
\hline Academic Committee & Constituted by the academic coordinators of the Schools of Nursing. \\
\hline Ad Hoc Scientific Committee & $\begin{array}{l}\text { Representatives from other scientific areas of university, health secretariat, } \\
\text { national drug control commissions, and experts on drug issues, etc. }\end{array}$ \\
\hline Secretary & Part-time administrative support for the activities of the project. \\
\hline
\end{tabular}

\section{Project's basic components}

The three basic components of the project provide the scientific basis of future nursing pro- fessionals to develop an understanding of drug issues in Latin America. The three basic components are presented in picture 2 .

\section{Picture 2 - Basic components of the project}

\begin{tabular}{|l|l|}
\hline \multicolumn{1}{|c|}{ Areas } & \multicolumn{1}{c|}{ Activities } \\
\hline Education activities & $\begin{array}{l}\text { a) Faculty training seminars on drug issues. } \\
\text { b) Nursing curriculum development with drug-related content at undergraduate and } \\
\text { graduate levels. } \\
\text { c) Development of an evaluation and monitoring system of the curricula and graduates } \\
\text { from these nursing curricula. }\end{array}$ \\
\hline Outreach activities & $\begin{array}{l}\text { Implementation of outreach educational activities at the community level for high-risk } \\
\text { groups or specific population groups. }\end{array}$ \\
\hline Drug research studies & Implementation of drug-related studies according to the priorities of the countries. \\
\hline
\end{tabular}

The steps of implementing the activities of

sented in picture 3 . the project at the university level include is pre-

Picture 3 - Steps to implementing the activities of the project

\begin{tabular}{|l|l|}
\hline \multicolumn{1}{|c|}{ Steps } & \multicolumn{1}{c|}{ Activities } \\
\hline Step I & Socializing the project at the school of nursing and at the university environment. \\
\hline Step II & Providing drug-related faculty educational training seminars. \\
\hline Step III & Developing drug-related nursing curricula for undergraduate and graduate programs. \\
\hline Step IV & Implementing drug-related nursing curricula at undergraduate and graduate levels. \\
\hline Step V & Implementing drug-related outreach activities and drug research studies. \\
\hline Step VI & Evaluating and monitoring the program and graduates. \\
\hline Step VII & $\begin{array}{l}\text { Disseminating and exchanging scientific knowledge and experiences among the schools of nursing in the } \\
\text { Americas. }\end{array}$ \\
\hline
\end{tabular}

\section{Research capacity-building programs}

During 2002-2008, ES/CICAD developed a specialized technical and financial cooperation agreement with the University of São Paulo - School of Nursing of Riberão Preto (Brazil) to implement the "Regional research capacity-building program for nurses and health related professionals to study drug related issues in Latin America."11-13 This program is currently carried out by the Secretaria Nacional Antidrogas (SENAD/Brazil) and the Escola de Enfermagem de Ribeirão Preto (EERP) da Universidade de São Paulo (USP) - Brazil. From 2003 to the present, ES/CICAD has been implementing another advanced research capacity-building program entitled "International research capacitybuilding program for health related professionals to study drug issues in Latin America and the Caribbean"(IRCBP), which has been carried out in partnership with the University of Alberta-Faculty of Nursing in Edmonton/Canada (first offer 20032004), and the subsequent offers with the Center of Addictions and Mental Health (CAMH) (2006-to present) in Toronto/Canada. ${ }^{14-16}$ 


\section{ACHIEVEMENTS}

Since its inception in 1997, the ES/CICAD/ OAS Schools of Nursing Project in Latin America, has achieved many successful outcomes in the areas of education, outreach activities, and research. The results of these achievements are presented bellow with some concrete examples of the different activities developed in the areas of education, outreach and research.

\section{Education area}

Since 1997, more than 50,000 nursing students have been educated through ES/CICAD/OAS School of Nursing Project-sponsored curricula with drug-related content; more than 1000 nursing school faculty members have been trained on promotion of healthy and sustainable lifestyle, drug use and abuse prevention, treatment, rehabilitation, and social integration. More than 200 nursing professors/ researchers have received specialized training in research methodology applied to the study of drug issues in Latin America. This project has served as a model for subsequently initiated projects with the schools of medicine, public health, education, psychology, social work, and law. ${ }^{17-18}$

Working with more than 100 schools in 20 countries today, the ES/CICAD/OAS project is transitioning away from a single school or faculty model (nursing, education, etc.), toward an "integrated project" approach that draws on all relevant academic disciplines (law, sociology, and psychology, for instance) and has the broad support of the university administration.

Pictures 4 and 5 indicate the recommended hours for nursing drug curricula at undergraduate and graduate levels that came from the 2004 and 2010 ES/CICAD/OAS University Partnerships Meetings. The Schools of Nursing involved in the project, have prepared a recommendation report to CICAD/OAS, entitled "Basic competencies for nursing professional in the area of drug demand reduction in Latin America" for the Schools of Nursing in Latin America to follow and adjust the numbers of hours related to drug issues at undergraduate and graduate levels according to the new recommendations. ${ }^{17-19}$

Picture 4 indicates the increased numbers of hours related to drug content for undergraduate and specialization programs, from a minimum of 270 hours in 2004 to 312 hours in 2010 at undergraduate level, especially in the areas of treatment and rehabilitation. At specialization level, the increased was from 35 hours in 2004 to 257 hours in 2010, especially in the areas of treatment, rehabilitation and social integration.

Picture 4 - Recommended hours for the nursing drug curricula at undergraduate and specialization levels

\begin{tabular}{lcc}
\hline \multicolumn{1}{c}{ Area } & $\begin{array}{c}\text { 2004 Rio de Janeiro meeting } \\
\text { recommendations }\end{array}$ & $\begin{array}{c}\text { 2010 Panama meeting } \\
\text { recommendations }\end{array}$ \\
\hline Undergraduate & 80 & 142 \\
Health promotion & 100 & \\
Use and abuse prevention & 35 & 80 \\
Treatment & 15 & 60 \\
Rehabilitation & 40 & 30 \\
Social integration & $\mathbf{2 7 0}$ hours & $\mathbf{3 1 2}$ hours \\
\hline Total & Any specialty & Mental health and drugs specialty \\
\hline Specialty & 8 & 10 \\
\hline Health promotion & 10 & 175 \\
Use and abuse prevention & 7 & 24 \\
Treatment & 3 & 40 \\
Rehabilitation & 7 & $\mathbf{2 5 7}$ hours \\
Social integration & $\mathbf{3 5}$ hours & . \\
\hline Total & &
\end{tabular}

Note: The total number of hours recommended by each of the programs is to be distributed in the total years of each of the programs. For the specialty programs it includes also the development of the monograph. ${ }^{17-19}$

Picture 5 indicates also the changes in numbers of hours for drug content for graduate programs at Masters and Doctoral levels regarding drug content, for a minimum of 45 hours in 
2004 to 90 hours in 2010 at Masters level, and for a minimum of 45 hours in 2004 to 108 hours in 2010 at Doctoral level. The increase in hours were especially in the areas of rehabilitation and social integration in Masters and Doctoral degree programs.

Picture 5 - Recommended hours for nursing drug curriculum at masters and doctoral levels

\begin{tabular}{lcc}
\hline \multicolumn{1}{c}{ Area } & $\begin{array}{c}\text { 2004 Rio de Janeiro meeting } \\
\text { recommendations }\end{array}$ & $\begin{array}{c}\text { 2010 Panama } \\
\text { meeting recommendations }\end{array}$ \\
\hline Masters & Nursing masters degree general & $\begin{array}{c}\text { Nursing masters degree with } \\
\text { emphasis on drugs }\end{array}$ \\
Health promotion & 10 & 10 \\
Use and abuse prevention & 15 & 15 \\
Treatment & 7 & 10 \\
Rehabilitation & 3 & 45 \\
Social integration & 10 & 10 \\
\hline Total & $\mathbf{4 5}$ hours & $\mathbf{9 0}$ hours \\
\hline Doctoral & Nursing doctoral program & Nursing doctoral program with an \\
& & emphasis on drugs \\
Health promotion & 8 & 8 \\
Use and abuse prevention & 15 & 15 \\
Treatment & 10 & 10 \\
Rehabilitation & 5 & 30 \\
Social integration & 7 & $\mathbf{4 5}$ \\
\hline Total & $\mathbf{4 5}$ hours & $\mathbf{1 0 8}$ hours \\
\hline
\end{tabular}

Note: The total number of hours recommended is to be distributed in the total years of each masters and doctoral programs. It also includes the development of the Thesis and Dissertation. ${ }^{17-19}$

\section{Outreach activities}

The Schools of Nursing involved in the ES/ CICAD/OAS project in Latin America have implemented more than of 400 outreach activities at the community level. The majority of the activities targeted high-risk populations, students from the public educational system and university, as well as the general population, parents, health professionals from hospitals and health centers, drug users, retired population, and clients of non-governmental organizations. The activities focused on promotion of a healthy and sustainable lifestyle, prevention of drug abuse, and social integration. Some Schools of Nursing in Latin America have invested much more in this area than in previous years of the project, specially the schools of nursing from Argentina, Bolivia, Brazil, Colombia, Honduras, Mexico, and Peru. The ES/CICAD/ OAS has facilitated and encouraged publications of these experiences conducted by the Schools of Nursing in Latin America. ${ }^{18,20-21}$

\section{Drug research studies}

The Schools of Nursing involved in the ES/ CICAD/OAS project have implemented more than 500 research studies on drug-related issues, and published more than 270 scientific articles in peer reviewed journals from the research findings. The majority of the studies were related to promotion of a healthy and sustainable lifestyle, and risk prevention, with some other studies related to treatment and rehabilitation. The sample populations studied were: women, school children, adolescents, adults, industrial and assembly plant workers, addicts, high school and university students, faculty, and health professionals. The research findings have been incorporated into clinical protocols and technological processes, and used to support curriculum development, out-reach activities aimed at the community, the development of new research proposals on drug related issues, and drug policy design. The schools of nursing who have contributed more in this area are from Brazil, Mexico, Colombia, and Peru. The other schools of nursing from the other countries have contributed also but in less percentage. ${ }^{18-20}$

\section{Other activities}

In the years 1998 to 2012, ES/CICAD/OAS organized several international meetings with deans, associate graduate deans, presidents of professional nursing associations, nursing experts, and 
faculty related to drugs issues, where the results of the activities from the education, outreach, and research areas where presented and shared with the participants from the Americas and the Caribbean.

ES/CICAD/OAS also organized three international nursing research with the participation of nurse researchers from Latin America, Canada, and the United States.

Six supplements of the Latin-American Journal of Nursing were published by ES/CICAD and EERP-USP/Brazil, 2004; 2005 (2); 2008; 2010; 2011 , containing articles from the findings of the research studies conducted by the participants in the regional and international research capacitybuilding programs in Brazil and Canada.

One supplement of Nursing Text \& Context Journal was published by ES/CICAD/OAS and UFSC/DENF/Brazil in 2012 containing articles from the findings of the research studies conducted by the participants of the international research capacity-building program in Canada.

The findings from multicenter and individual drug research studies done by nursing faculty and researchers have been presented in national and international Nursing conferences, inside and outside of the nursing discipline in the Americas and Europe.

The Schools of nursing have also published educational flyers and drug prevention material used in educational activities at the community level.

ES/CICAD/OAS has created the "Schools of nursing drug addiction prevention networking - REEPA (Spanish acronym) hosted by the Faculty of Nursing at University of Nuevo Leon, Monterrey, Mexico. This ES/CICAD/OASSchools of Nursing Network is affiliated to the PAHO International Nursing Networking.

ES/CICAD/OAS has facilitated the participation of nursing faculty from Latin America in the preparation of chapters of two books published in the United States, and one book in Brazil:

- Wright MGM, Almeida MCP, Padilha MICS, David HMSL, Albuquerque GL, Silva J. Nursing in Brazil - Chapter 5. In: Breda KL, editor. Nursing and globalization in the Americas: a critical perspective. Amityville, New York: Baywood Publishing Company, Inc; 2009. p.137-83.

- Duque-Paramo MC, Padilha MICS, Sanhueza OA, Castillo MMA, Castellanos FS, Lopez KSG, Flores YP. Qualitative nursing research in Latin America: the cases of Brazil, Chile, Colombia and Mexico. In: Beck CT, editor. Routledge Inter- national handbook of qualitative nursing research. New Yourk: Routledge; 2013. p.478-99.

- Comisión Interamericana para el Control del Abuso de Drogas de la Secretaria para la Seguridad Multidimensional de la Organización de los Estados Americanos, University of São Paulo, School of Nursing of Ribeirão Preto/Brazil. El fenómeno de las drogas: implicaciones para la salud internacional e investigación. Ribeirão Preto (BR): University of São Paulo, School of Nursing of Ribeirão Preto; 2012.

\section{Outcomes}

The outcomes of ES/CICAD/OAS Schools of Nursing Project in Latin America can be seen in the following areas:

\section{Advancement of nursing education, professional leadership, and the work force in Latin America}

ES/CICAD/OAS recognizes the importance and contribution of nursing professional in the areas of promotion of healthy and sustainable lifestyles, drug abuse prevention, treatment, rehabilitation, and social integration, and has provided technical and financial support to advance nursing education in Latin America.

ES/CICAD/OAShas expanded the Schools of Nursing Project to other Schools of Nursing in each of the participant countries through a partnership with the National Association of Schools of Nursing.

The ES/CICAD/OAS Schools of Nursing Project has facilitated the integration of efforts and expertise from multiple disciplines and from the health sector to discuss drug related issues in the university environment.

New models of nursing leadership were created in Latin America at international, national and university levels.

\section{Advancement of nursing scientific knowledge, dissemination exchange and policy design related to drug issues in Latin America}

A movement was initiated among universities and nursing professional associations to base social practice on scientific evidence to improve the quality of care within the health care system and drug treatment centers in Latin America.

Nursing research studies have generated new nursing education models and nursing tech- 
nologies to improve the services provided to people with drug addictions.

A multi-centric pilot study related to "Drug, women and violence in the Americas" involving 22 universities (19 Schools from Latin America and three from the United States), was developed, implemented and used as a reference for follow up studies in this issue in other countries in Latin America and the Caribbean.

The number and dissemination of scientific nursing publications concerning drug related issues increased in both Latin America and in the Caribbean.

The contribution of this project to reduction of drug use and abuse on countries of Latin America remain a long term goal to be measured.

\section{FINAL CONSIDERATIONS}

The ES/CICAD/OAS Schools of Nursing Project has proved to be a successful initiative. Through this project, the ES/CICAD/OAS has developed a process and methodology to work with universities in Latin America that has no other precedent. The model for curriculum development with drug-related content has been used as a guide for other schools of nursing in Latin America and the Caribbean. The experience that ES/CICAD/ OAS has acquired in working with the universities and schools of nursing has facilitated the expansion of this tool to other academic areas such as: schools of medicine, public health, education, psychology, social science, social communication, and law.

ES/CICAD/OAS developed with the universities a unique approach to introducing drugrelated content in undergraduate and graduate curricula, as well as outreach activities and drug research studies on issues that are very important to CICAD member states.

The expansion of this experience to other schools of nursing in Latin America and in the Caribbean, as well as to other academic areas such as medicine, public health, education, etc, has allowed ES/CICAD/OAS to work with the universities to develop interdisciplinary and integrated projects that involve all academic areas. Models of integrated projects have been implemented at universities in El Salvador, Nicaragua, Paraguay, Peru, and in the Caribbean.

The international and regional research capacity-building programs for nurses and health related professionals to study drug-related issues in Latin America and in the Caribbean has demonstrated the importance of the continuing need to develop human resources in this area to support policy design, decision-making, and project development based on scientific evidence.

\section{RECOMMENDATIONS}

ES/CICAD/OAS should develop strategies to facilitate knowledge transfer/exchange among all universities/schools and national drug control commissions, as well as research centers, to support policy design and decision-making.

ES/CICAD/OAS should continue to support the development and implementation of more interdisciplinary and integrated drug related issues projects within the universities in Latin America and the Caribbean;

ES/CICAD/OAS should provide incentives for National Drug Commissions in partnership with the Ministries of Education to develop and implement "National drug strategic plan for the universities" in Latin America and the Caribbean.

\section{ACKNOWLEDGMENTS}

We would like to thank the Governments of Japan, United States, Canada, and Brazil for their steadfast support for this project; the former Executive Secretaries of CICAD, Ambassador David Beall, and Ambassador James Mack; former Head of Demand Reduction Section of CICAD, Dr. Anna McG Chisman, and Embassador Paul Simons, the new Executive Secretariat of CICAD, Rafael Franzini, Adjunct Executive Secretariat of CICAD, and the new Head of Demand Reduction Section of CICAD, Alex Hill for their technical support and collaboration; the authorities of all universities, professors and students involved in the project in Latin America and the Caribbean. A special thanks goes to Dr. Karen L. Breda for the final revision of the English language of the paper.

\section{REFERENCES}

1. World Health Organization. World Health Report: working together for health. Geneva $(\mathrm{CH})$ : World Health Organization; 2006.

2. Inter-American Drug Abuse Control Commission (CICAD). Multilateral Evaluation Mechanism (MEM). Washington, DC (US): Rounds; 2009.

3. Cornia GA. Globalization and health: results and options. Bull World Health Organ. 2001; 79(9):83441. Epub 2001 Oct 23 
4. Dollar D. Is globalization good for your health? Bull World Health Organ. 2001; 79(9):827-33. Epub 2001 Oct 23.

5. OAS/CICAD. Challenges for a new future-1999-2004. Washington, DC (US): OAS; 2004

6. CICAD/SSM/OAS. Hemispheric drug strategy - plan of action 2011-2015. Washington, DC (US): CICAD; 2011.

7. Spricigo JS, Rdünz V, Fenili RM, Souza ML. The role of the nursing profession in the area of drug demand reduction. In: Wright MGM, Chisman AMcG, Padilha MICS, Gelbcke FL, Spricigo JS, Pires DEP, et al, editores. The role of the nursing profession and the drug phenomenon in Latin America. Florianópolis (SC): OAS/CICAD/UFSC; 2006. p.93-102.

8. Wright MGM. A critical-holistic paradigm for an interdependent world. Am Behav Sci. 2000 Feb; 43(5):808-24.

9. Wright MGM. The contribution of Graduate-Degree Nursing Programs and the drug phenomenon in Latin America: a critical-holistic analysis. In: Wright MGM, Chisman AMcG, Padilha MICS, Gelbcke FL, Spricigo JS, Pires DEP, et al, editores. The role of the nursing profession and the drug phenomenon in Latin America. Florianópolis (SC): OAS/CICAD/ UFSC; 2006. p.15-22.

10. Wright MGM. El análisis crítico-holístico de los programas de postgrado de enfermería frente a los desafíos de la reducción de la demanda de drogas en América Latina. In: Wright MGM, Chisman AMcG, Padilha MICS, Gelbcke FL, Pires DEP, Radunz $\mathrm{V}$, et al, editores. La situación de los Programas de Postgrado de Enfermería en nueve países de América Latina frente a los desafíos de la reducción de la demanda de drogas. Florianópolis (SC): OAS/ CICAD/UFSC; 2003. p. 15-22.

11. Mendes IAC, Luis MAV. (Editorial). Uso de Substancias psicoactivas, un nuevo viejo desafío. Rev Latino-Am Enfermagem. 2004; 12(Esp):295-6.

12. Wright MGM, Chisman AMcG, Mendes IAC, Luis MAV, Carvalho EC, Mamede MV. El papel de la cooperación técnica \& financeira para el avance de la profesión de enfermería en el área de reducción de la demanda de drogas en América Latina: desafíos y perspectivas. Rev Latino-Am Enfermagem. 2004; 12(Esp):301-6.

13. Luis, MAV, Mendes, IAC, Carvalho, EC, Mamede, MV, Wright, MGM, Chisman, AmcG. Experiência de parceria entre universidade e organismo internacional capacitando enfermeiros docentes da América Latina para la investigación del fenomeno de las drogas. Rev Latino-Am Enfermagem. 2004; 12(Esp):307-15.

14. Wright MGM, Caufield C, Gray G, Olson J. International research capacity-building programs for nurses to study the drug phenomenon in Latin America: challenges and perspectives. Rev LatinoAm Enfermagem. 2005; 13(Esp):1095-101.

15. Wright MGM, Caufield C, Gray G, Olson J, Ludeña AC, Oblitas FYM, et al. International nursing leadership related to the drug phenomenon: a case study of the partnership experience between the Inter-American Drug Abuse Contyrol Commission (CICAD) and the University of Alberta-Faculty of Nursing. Rev Latino-Am Enfermagem. 2005; 13(Esp):1102-17.

16. Wright MGM, Cumsille F, Khenti A, Padilha MI. Editorial. Texto Contexto Enferm. 2012; 21(Esp):11-2.

17. Wright MGM, Stein A, Galvis MB, Rodrigues BMRD, Oliveira SA, Henriques RLM, et al. El currículo de enfermería con el contenido de drogas para los programas de pregrado y ostgrado: la experiencia de la CICAD en América Latina. Rio de Janeiro (BR): ES/CICAD/OAS, UERJ; 2004.

18. Wright MGM. Luján MJ, Oblitas FYM, Alayo M. La contribución de las escuelas de enfermería en el área de reducción de la demanda de drogas en América Latina. Washington, DC (US): ES/CICAD/OAS, Mosaic Express; 2012

19. Wright MGM, Luján MJ, Alonso MM, Esparza SE, editores. Competencias básicas del profesional de enfermería en el área de la reducción de la demanda de drogas en América Latina. Washington, DC(US): Mosaic Express, ES/CICAD/OAS; 2012.

20. Wright MGM, Chisman AM, Sarmiento MA, Salaza, MC, Phum ET, editors. La contribución de las escuelas de enfermería en el campo del fenómeno de las drogas en América Latina: un proceso en construcción liderado por la CICAD/OEA. Lima (PE): ES/CICAD/OAS, Universidad Peruana Cayetano Heredia; 2005.

21. Castillo MMA, Gracía KSL, Rodriguez NNO, Facundo FRG. Liderazgo en la prevención de uso y abuso de drogas: una experiencia. Monterrey (MX): Universidad Autónoma de Nuevo León, Serie tendencia; 2012 